\title{
An Analysis of Employment and Government Expenditure on Economic Growth In Central Kalimantan Province
}

\author{
Aprilia Anggraeni ${ }^{1}$, Elia Kalontong ${ }^{2}$, Alexandra Hukom ${ }^{3}$ \\ \{she.aprilia89@gmail.com¹, ekalontong@gmail.com², alexandra.hukom@feb.upr.ac.id ${ }^{3}$ \} \\ Magister of Economic, Post Graduate Program University of Palangka Raya ${ }^{1}$, \\ Magister of Economic, Post Graduate Program University of Palangka Raya ${ }^{2}$, \\ Lecture at Faculty of Economics, University of Palangka Raya ${ }^{3}$
}

\begin{abstract}
The main objective of this study was to analyse influence of employment and government expenditure on economic growth in Central Kalimantan Province for the period 2013-2017. The research approach is quantitative descriptive. The sample in the study were 13 regencies and 1 city in Central Kalimantan Province. The analysis was carried out by multiple linear regression using the IBM SPSS version 24.0 application. The results of the study show that partialy, employment has a positively and significant influence on economic growth, while government expenditure has no significant influence on economic growth. However, simultaneously employment and government expenditure has a positevely and significant influence on economic growth in Central Kalimantan Province.
\end{abstract}

Keywords: Employment, Government Expenditure, and Economic Growth.

\section{Introduction}

Since the issuance of Law Number 23 of 2014 about Regional Government which has been amended several times, the latest by Law Number 9 of 2015, regional governments are given extensive authority to manage their own households with as little interference as possible from the central government. Giving regional autonomy influences the economic growth of a region because it gives freedom to local governments to make their own financial plans and make policies that can influence the progress of their region. Development is a multi-dimensional process that involves major changes in social structures, trained mental attitudes and national institutions including acceleration of economic growth, absolute reduction in inequality and eradication of poverty [1].

Economic growth is an expansion of economic activity and becomes the only way to increase the income of community members and open new employment opportunities [2]. Economic growth is a process of increasing productive capacity in an economy continuously or continuously all the time so as to produce a level of income and national output that are increasingly greater. Economic growth is also defined as the process of increasing output per capita in the long term. The indicator for measuring economic growth in an area is Gross Domestic Regional Product (GDRP), which describes the quantity of goods and services produced by all production units [3].

In the implementation, high economic growth is the main target for developing countries. Economic growth that occurs during a certain period can not be separated from the 
development of each sector or sub-sector that contributes to form the added value of an area's economy. High economic growth often still leaves problems that must be faced in the development of a region, including differences in the rate of growth between regions that have caused a gap in prosperity and progress between regions, as well as income distribution imbalances due to not paying attention to whether the growth is greater or smaller than the level of population growth or changes in economic structure.

Data from Central Bureau of Statistics (BPS) of Central Kalimantan Province (2018) shows that Central Kalimantan's economy grew 6.74 percent in 2017, up from 6.36 percent in the previous year, while on the Kalimantan region, economic growth of Central Kalimantan Province was the highest and also higher than the national economic growth of 5.07 percent at the same period [4]. The level of progress and economic development can be seen from the results of economic activities by comparing sectors that make the greatest contribution to increasing economic growth in Central Kalimantan Province. Sectors that contribute to income or substantial added value to economic growth include the employment and government expenditure.

Employment is one of the capital for the sustainable of development, the number and composition of the employment will continue to change along with the ongoing demographic process. If the ability of an area in the process of producing goods and services increases, the need for employment input also increases, thereby expanding the absorption of employment opportunities. Labor can be defined as anyone who is able to do work to produce goods and services both to meet their own needs and for the community. The working age population is those who are 15 years or older. So that everyone or residents who are 15 years old and above are classified as labor [4].

Employment in an economy is one of the factors that can drives economic growth. Investment in fostering human resources can increase human capital, so that in the end it will bring the same positive impact on production numbers, even greater considering the continued increase in the number of humans [1]. Employment is also defined as the amount of labor absorbed in a sector in a given time [5].

According to the Central Bureau of Statistics (BPS) of Central Kalimantan Province, in the year of 2017, in Central Kalimantan Province, employment reached 1,222,707 people in working age, and the agriculture sector was the highest sector in employment, which were 490,488 people [4].

In addition employment degree is one of a driving factor for economic growth in a region. There is one other important factor, which is the participation of the government. The role of the government is very important to regulate economic activities, control economic stability and improve the economy of the region.

According to Keynes Theory, the government entered into the economy through policies taken and implemented [6]. The fiscal policy adopted by regional governments is shown by the Revenue and Expenditure Regional Budget (APBD) which is set every year. In addition, what sectors are the priority of government policy can also be reflected in the allocation of expenditure budgets [7].

Expenditures by the regional government (provincial and regency or city) reflected in the APBD are divided into two main groups, namely routine expenditure or regional apparatus expenditure and development expenditure or public service expenditure. From the two types of expenditures, routine expenditure or regional apparatus expenditure is the dominant type of expenditure in development expenditures in most regions both in Central Kalimantan Province and in most regions in Indonesia. Routine expenditures or regional apparatus expenditures include personnel, goods, maintenance, official travel, loans and interest and subsidies. All 
types of expenditure are in nature consumption expenditures. While development expenditure or public service expenditure is divided according to development sectors which are more as accumulations of capital stock. The above conditions are expected to be of concern of the governments to increase the allocation of development expenditures to stimulate economic growth.

Economic growth is influenced by various factors including available land and natural resources, population number and quality, number and quality of labor, availability of capital goods and technology as well as government participation. In the Solow-Swan theory, economic growth depends on the availability of factors of production (population, labor, and capital accumulation) and the level of technological progress. This theoretical view is based on classical economic analysis, namely that the economy is in full employment and full utilization of production actors. In other words, the economy will continue to grow and it all depends on population growth, capital accumulation, and technological progress [8].

In economic growth the number of employment who work is one of the factors that will affect economic growth in a region. In addition to production factors, the number of employment who work will also increase from year to year so that when utilized to the maximum it will increase economic growth. Several studies show that employment has significant effect on economic growth in DIY Province [9]. Furthermore, government expenditure has significant effect on economic growth in Bengkulu Province [10] and on the other hand, government expenditure also has no significant effect on economic growth in Indonesia [11]. Simultaneously, employment and government expenditure has significant effect on economic growth in Java Island [12].

Hence the primary objective of the study is to analyse the effect of employment and government expenditure on economic growth in Central Kalimantan Province in the period 2013-2017. It is also to find possible solutions to the problem of large scale employment creation and to make a good planning for the efficiency and effective of government expenditure budgeting. The study is also significant in that its results may be used by government and practitioners to improve employment degree and increase the allocation of government expenditure budgeting for public service as accumulation of capital stock or asset to stimulate economic growth both in Central Kalimantan Province and Indonesia for economic growth of the country.

\section{Methods}

This research is a type of quantitative research with secondary data obtained from the Central Bureau of Statistics (BPS). Data is processed into panel data, namely data crosssection from 13 Regencies and 1 City in Central Kalimantan Province and data time series from 2013-2017. Data analysis was carried out with using IBM SPSS version 24.0 program. The basic model that will be used in this study is as follows.

$$
\mathrm{PE}_{\mathrm{it}}=\beta_{0}+\beta_{1} \log \mathrm{TK}_{\mathrm{it}}+\beta_{2} \log \mathrm{PP}_{\mathrm{it}}+\varepsilon_{\mathrm{it}}
$$

Where, PE: economic growth variable (percentage), TK: employment variable (number), PP: government expenditure variable (number), $\beta_{0}$ : constant, $\beta_{1}, \beta_{2}$ : regression coefficient, regency/city, t: year $\varepsilon$ : error term. The formula in this study is $\mathrm{Y}=\mathrm{a}+\mathrm{bx}_{1}+\mathrm{bx}_{2}$. Analysis of data was carried out using validity and reliability test and multiple linear regression test. 


\section{Results and Discussion}

\subsection{Validity and Reliability Test}

Validity test is done by comparing the $r$ count and $r$ table. If $r$ count is greater than $r$ table then the data item is valid, and if $r$ count is smaller than $r$ table, the data item is considered invalid. Based on the results of the SPSS test, the validity of the sample of 13 Regencies and 1 City the average value is above 0.90 ( $\mathrm{r}$ table 0.44 ), the data instruments of the above variables are valid. This means that the data presented is valid statistically and can be used for further analysis.

Reliability test is done by comparing the Cronbach Alpha numbers to a minimum with the provisions of Cronbach Alpha value must be above 0.60. If Cronbach Alpha is above 0.60, the data used is reliable. From the results of the reliability test on the SPSS program by using secondary data, it is found that the value of Cronbach Alpha is 0.739 or 73.9 means that the data used is feasible and can be used for firther anaysis.

\subsection{Multiple Linear Regression Test (Hypothesis Test)}

Multiple linear regression test analysis is done to test the research hypothesis where the influence between $\mathrm{X}$ and $\mathrm{Y}$ variables. $\mathrm{X}$ variable is the independent variable, while the $\mathrm{Y}$ variable is the dependent variable. The $\mathrm{X}$ variable in this study is employment and $\mathrm{Y}$ variable is government expenditure. While the $\mathrm{Y}$ variable is Central Kalimantan's economic growth [13]. The hypothesis in this study:

H1 : There is an influence between employment on economic growth.

H2 : There is an influence between government expenditure on economic growth.

H3 : There is an influence between employment and government expenditure on economic growth.

Table below show the results of $\mathrm{t}$ test (partial) and $\mathrm{F}$ test (simultaneous) as an output of the SPSS analysis produce the following equation:

Table 1. Output of the SPSS Analysis

\begin{tabular}{lll}
\hline Formula & $:$ & $\mathrm{PE}=5770,43+0,71 \mathrm{TK}-0,000001395 \mathrm{PP}$ \\
$\mathrm{t}$ count & $:$ & $(4,680)^{*}(-0,491)$ \\
F count & $:$ & $(35,767)^{*}$ \\
$\mathrm{R}^{2}$ & $:$ & $87 \%=0,867$ \\
\hline
\end{tabular}

T Test. The $\mathrm{t}$ test is known as a partial test, which is to test how the influence of each independent variable individually on the dependent variable. This test can be done by comparing $t$ count with $t$ table or by looking at the column of significance in each $t$ count.

It is known that the variable of employment $\left(\mathrm{X}_{1}\right)$ has a value of $t$ count is 4,680 . While the $t$ table value is 1.76 . $t$ value calculated from employment variable $\left(X_{1}\right)$ is higher than $t$ table $(4,680>1.76)$. It means, there is a positively and significant influence between employment on economic growth. It can be concluded that $\mathrm{H} 1$ is accepted.

While for the variable government expenditure $\left(\mathrm{X}_{2}\right)$ has a value of $t$ count -0.491 . It can be seen that the calculated $t$ value is smaller than $t$ table $(-0.491<1.76)$. Because $t$ count is smaller than $\mathrm{t}$ table for government expenditure variable, it means that government 
expenditure has no significant influence on economic growth. It can be concluded that $\mathrm{H} 2$ is rejected.

F Test. F Test test is used to determine the influence of independent variables together (simultaneous) on the dependent variable. The F test results are seen in the Anova table in the Significance column. From the results of the Anova test for simultaneous testing, it is known that the significance value is 0.00 with a calculated $F$ value of 35.767 . F table for a sample of 14 regencies/cities and time series data 2013-2017 $(\mathrm{n}=5)$ is 3.63. It is known that the calculated $F$ value is greater than the $F$ table value $(35,767>3.63)$. It can be concluded that there is a positively and significant influence between employment and government expenditure on economic growth. If the two variables are combined, it will greatly affect economic growth (Y).

Influence of Employment on Economic Growth. Based on the results of the study it was found that employment was able to influence economic growth. This explains that the role of the employment is able to stimulate economic growth in Central Kalimantan Province. The results of this study were also in line with the research made by Fitriani (2018) with the title Effect of Employment and Government Expenditures on Economic Growth of DIY Province in 2007-2015 [9]. The purpose of this study was to determine the effect of employment and government expenditure on economic growth in Daerah Istimewa Yogyakarta Province in 2007-2015. The results of the study showed that employment has a positive and significant effect on economic growth in Daerah Istimewa Yogyakarta Province.

One of the factors that influence economic growth is the availability of jobs and the ability of the government to carry out strategies so that the working age population can be productive and able to increase GDRP. There are some notes by researchers where the employment in Central Kalimantan Province is able to persist from year to year in the midst of a sluggish regional economy where major sectors, such as mining have experienced declines in recent years. Nevertheless Central Kalimantan Province is able to maintain employment by increasing other sectors, such as plantations and forestry, given that millions of hectares of land have been converted into palm oil plantations in the southwestern part of Central Kalimantan Province. This becomes a breath of fresh air for the employment creation. In addition, the economic growth of Central Kalimantan Province can reduce unemployment from year to year.

Influence of Government Expenditure on Economic Growth. Based on the results of the study showed that government expenditure has no significant impact on economic growth in Central Kalimantan Province. This shows that government expenditure is not effective and efficient for the investment of public service. It can be said that allocation of government expenditure without consider the priority of development program, especially for public service that can produce investment. Government expenditure is also intended to conduct financial stability towards the primary needs of the community such as education, health, infrastructure, and personnel expenditure. Furthermore, government expenditure is not specifically intended to increase macroeconomic growth. The results of this study were supported by Ristiananingsih (2013) who examined the effect of government expenditure on economic growth in Indonesia [11]. The results of the study show that in the aggregate model the effect of government expenditure has no significant impact on economic growth, both in the long and short term. This indicates that the budget allocation for government expenditure is still not efficient, so that it cannot encourage economic growth in Indonesia. 
Influence of Employment and Government Expenditure on Economic Growth. Results of the $\mathrm{F}$ test or simultancy found that the calculated $\mathrm{F}$ value is greater than the $\mathrm{F}$ table with a significance value equal to 0.00 . It means that employment and government expenditure has a positive and significant influence on economic growth in Central Kalimantan. This is supported by the calculated of $F$ value with 35,767 which means that if the two variables (employment and government expenditure) are joined, it will be able to support the economic growth of a region. Absorption of employment and government expenditure is very good and balanced and it will have an impact on increasing of GDRP, which in turn will stimulate positive economic growth.

The results of this study were supported by Buana, Saragih, and Aritonang (2018) who examined the effect of government expenditure, government investment, private investment and employment on economic growth in Java [12]. The results showed that government expenditure, private investment and employment had a positive effect on economic growth on the Island of Java.

\section{Conclusion}

From the research results, it can be concluded that partially, employment has a significant influence on the economic growth. It means that the increasing of employment degree will promote economic growth. Government expenditure has no significant influence on economic growth. This is possible due to the fact that government expenditure is not capable to stimulating the GDRP of an area in Central Kalimantan Province. It is caused by routine expenditure or regional apparatus expenditure is the dominant type of expenditure in development expenditures in most regions both in Central Kalimantan Province and in most regions in Indonesia than development expenditure or public service expenditure. Simultaneously, employment and government expenditure has a significant influence on economic growth in Central Kalimantan Province. This is supported by the results of research in which if the employment degree and government expenditure are increase, it will promote economic growth in Cental Kalimantan Province. Recommendations were also made regarding solution for job creations in Central Kalimantan Province by looking at the workforce as needed by the industry, so that the absorption of the workforce will have an impact on increasing income per capita and growth in GDRP. For next researchers, it is expected to consider adding other variables that have relations with economic growth, such as intervening variable, so that further research will be better. 


\section{References}

[1] Todaro, M.P. and Smith, S. C.: Pembangunan Ekonomi. Jilid 1 Edisi Kesebelas. Erlangga, Jakarta (2013)

[2] Boediono. : Ekonomi Indonesia Mau ke Mana? Kumpulan Esai Ekonomi. Edisi Ketiga. KPG (Kepustakaan Populer Gramedia), Jakarta (2010)

[3] Waryanto, P.: Pengaruh Belanja Modal terhadap Pertumbuhan Ekonomi. Jurnal Perbendaharaan, Keuangan Negara dan Kebijakan Publik, Vol.2 No.1, pp. 35-55 (2017)

[4] Badan Pusat Statistik Provinsi Kalimantan Tengah: Statistik Daerah Provinsi Kalimantan Tengah Tahun 2018. Badan Pusat Statistik Provinsi Kalimantan Tengah (2018)

[5] Fridhowati, N.: Faktor-Faktor Yang Mempengaruhi Penyerapan Tenaga Kerja Sektor Industri di Pulau Jawa. Skripsi. Departemen Ilmu Ekonomi, Fakultas Ekonomi dan Manajemen Institut Pertanian Bogor (2011).

[6] Sumardjoko, I.: Analisis Efisiensi Belanja Langsung Melalui Penguatan Belanja Modal Daerah dan Implikasinya Terhadap Pertumbuhan Ekonomi Regional, Jurnal Defis Edisi 1, Volume I, JuliDesember 2017. pp. 71-90 (2017)

[7] Putra, W.: Tata Kelola Ekonomi Keuangan Daerah. Edisi 1 Cetakan ke-1. Rajawali Pers, Jakarta (2018)

[8] Arsyad, L.: Pengantar Perencanaan Pembangunan Ekonomi Daerah. Edisi Ketiga. BPFE, Yogyakarta (2016)

[9] Fitriani, N.: Pengaruh Tenaga Kerja dan Pengeluaran Pemerintah Terhadap Pertumbuhan Ekonomi Provinsi DIY Tahun 2007-2015. Jurnal Pendidikan dan Ekonomi, Volume 7, Nomor 1, pp.1-9 (2018)

[10] Anitasari, M., and Soleh, A.: Pengaruh Pengeluaran Pemerintah Terhadap Pertumbuhan Ekonomi di Provinsi Bengkulu. Jurnal Ekombis Review, Vol. 3, No. 2, pp. 117-127 (2015)

[11] Ristiananingsih, I.: Pengaruh Pengeluaran Pemerintah Terhadap Pertumbuhan Ekonomi di Indonesia Tahun 1970-2011. Tesis. Universitas Gadjah Mada (2013)

[12] Buana, A. L., Saragih, H. J. R., and Aritonang, S.: Pengaruh Pengeluaran Pemerintah, Investasi Pemerintah, Investasi Swasta dan Tenaga Kerja terhadap Pertumbuhan Ekonomi Di Pulau Jawa Tahun 2011 - 2015. Jurnal Ekonomi Pertahanan Vol. 4, No. 2, pp. 1-20 (2018)

[13] Gunawan, I.: Pengantar Statistika Inferensial. Cetakan ke-2. Rajawali Pers, Jakarta (2017) 